\title{
Impact of Sorghum extract type, concentration and application time on weeds dry weight, cost benefit ratio and harvest index of Wheat
}

\author{
Abdul Rab ${ }^{1 *}$, Shad Khan Khalil ${ }^{1}$, Gul Sadiq ${ }^{1}$, Muhammad Asim², Nasir \\ Mehmood $^{3}$, Haneef Raza ${ }^{4}$, Aman Khan ${ }^{2}$, Haq Nawaz ${ }^{1}$, Faisal Khan ${ }^{1}$ and \\ Izhar Ali ${ }^{1}$ \\ 1. Department of Agronomy, University of Agriculture Peshawar-Pakistan \\ 2. Department of Agronomy, University of Agriculture Faisalabad-Pakistan \\ 3. Department of Plant Protection, University of Agriculture Peshawar, Khyber Pakhtunkhwa-Pakistan \\ 4. Department of Agriculture, University of Swabi, Khyber Pakhtunkhwa-Pakistan \\ *Corresponding author's email: abdulrab@aup.edu.pk \\ Citation \\ Abdul Rab, Shad Khan Khalil, Gul Sadiq, Muhammad Asim, Nasir Mehmood, Haneef Raza, Aman Khan, Haq \\ Nawaz, Faisal Khan and Izhar Ali. Impact of Sorghum extract type, concentration and application time on weeds \\ dry weight, cost benefit ratio and harvest index of Wheat. Pure and Applied Biology. Vol. 5, Issue 4, pp1008-1018. \\ http://dx.doi.org/10.19045/bspab.2016.50126
}

Received: 07/06/2016

Revised: 29/08/2016

Accepted: 03/09/2016

Online First: 09/09/2016

\section{Abstract}

A field trial was conducted at Agricultural University Peshawar in year 2014-15 to evaluate effect of sorghum extract type, concentration and application time on weeds dry weight, cost benefit ration and harvest index of wheat. Randomized complete block design (RCBD) with three replications was used. Experiment was composed of two sorghum extract types (stem and leaf extract), three extract concentrations $\left(1: 3,1: 4\right.$ and 1:5 $\left.\mathrm{kg} \mathrm{L}^{-1}\right)$ and three application time (emergence (E), tillering $(\mathrm{T})$ and $50 \%$ at $\mathrm{E}+50$ at $\mathrm{T})$. Herbicides $(\mathrm{H})$ treated, hand weeding $(\mathrm{HW})$ and control plots were included in each replication for comparison. $\mathrm{H}$ treated plots gave fewer weeds dry weight $\left(32.1 \mathrm{~g} \mathrm{~m}^{-2}\right)$, more grains spike ${ }^{-1}$ (50.9), heavier spike weight (3.40 g), more harvest index (H.I) (37.9\%), more gross income (G.I) (Rs.208750 ha ${ }^{-1}$ ), more net return (N.R) (Rs. 175510 ha $^{-1}$ ) and higher value cost ratio (V.C.R) (6.6). Among concentrations sorghum water extract (SWE) applied with 1:3 concentration produced lighter weeds dry weight $\left(66.7 \mathrm{~g} \mathrm{~m}^{-2}\right)$, more grains spike ${ }^{-1}$ (47.6), heavier spikes weight $(2.40 \mathrm{~g})$, higher H.I (30.2 \%), more G.I (Rs.194653 ha-1), more N.R (Rs. $156746 \mathrm{ha}^{-1}$ ) and higher V.C.R (5.6). Among application time SWE applied at tillering resulted in lesser weeds dry weight $\left(68.2 \mathrm{~g} \mathrm{~m}^{-2}\right)$, more grains spike ${ }^{-1}$ (45.5), more spike weight $(2.90 \mathrm{~g})$, maximum H.I (34.4 \%), more G.I (Rs.188025 ha-1), more N.R (Rs. 157083 ha $^{-1}$ ) and higher V.C.R (5.8). Leaf water extract (LWE) produced lighter weeds dry weight $\left(70.8 \mathrm{~g} \mathrm{~m}^{-2}\right)$, more grains spike-1 (45.3), heavier spike weight (2.80 g), high H.I (34 \%), more G.I (Rs.189616 ha ${ }^{-1}$ ), less N.R (Rs. 156746 ha $^{-1}$ ) and lower V.C.R (4.8) compared with stem water extracts. It is concluded that LWE applied with 1:3 concentration sprayed at tillering reduced weeds dry weight and increased grains spike ${ }^{-1}$, spike weight and harvest index of wheat and is recommended for decreasing weeds dry weight and increasing H.I of wheat and farmer profit in agro climatic condition of Peshawar.

Keywords: Sorghum stem and leaf extracts; Weeds dry weight; Harvest index; Cost benefit ratio; Wheat Introduction

Wheat (Triticum aestivum L.) is used as food for human and feed for livestock [1]. The cultivated arable land under wheat was 9.20 million ha with 25.98 million tons production and 2.82 tons $\mathrm{ha}^{-1}$ yield [2]. Although Pakistan is among the top ten wheat producing country but, its average 
wheat yield (2.82 tons $\left.\mathrm{ha}^{-1}\right)$ is far below the yield of advanced wheat growing countries [3]. Besides other factors limiting wheat yield, weeds infestation is considered the major cause of lower yield. Weeds reduce wheat yield by 20 to $30 \%$ in Pakistan [4] worth Rs. 30 billion monetary losses alone in Pakistan [5]. About 37 injurious weeds species grow in wheat fields including wild oat (Avena fatua), lambsquarters (Chenopodium album), canary grass (Phalaris minor), field bindweed (Convolvulus arvensis), annual bluegrass (Poa annua), canada thistle (Cirsium arvensis) and broad leaf dock (Rumex dentatus) [6].

Generally farmers use synthetic herbicides for weeds control. However, unwise use of commercial herbicides may cause weeds resistant to herbicides, pollute the environment, underground water and health threats in human and animals [6]. Out of the total utilization of pesticides in Pakistan, herbicides are consuming about $14 \%$ and almost $63 \%$ of the total imported herbicides were utilized on wheat, which worth Rs. 2.2 billion [7].

Sorghum (Sorghum bicolor L.) being an allelopathic crop holds various allelochemicals which reduces weeds growth [8]. Sorgoleone secreted by sorghum roots effect the growth of neighboring plants [9]. Many sorghum cultivars were found to have inhibitory effect on growth of weeds [10]. The efficiency of allelochemicals varies from plant to plant and their parts [11]. Allelochemicals were found in roots, stems, leaves, flowers and seeds of allelopathic crop [12]. Several essential secondary metabolites such as phenolic, alkaloids, flavonoids, and terpeniods were identified in sorghum plants [13]. The phenolics present in sorghum comprised benzoic acid, caffeic acid, ferulic acid, gallic acid, syringic acid, coumaric acid and chlorogenic acid [14] which are phytotoxic to the growth of certain weeds and can reduce weeds density and growth [15]. Phenolic compounds in small amount have stimulatory effect on growth and germination of plants, whereas they have inhibitory effect on growth and germination of plants in higher quantity [16].

Many researchers studied allelopathic effect of sorghum water extract for suppressing weeds and increasing yield of wheat. An ideal substitute for reducing dependency on commercial herbicides is the application of allelopathic crops water extract as foliar spray [17]. Sorghum water extract applied as foliar spray decrease density of weeds by 15-17 and weeds dry weight by 19 to $49 \%$ [18]. Sorghum root water extract decrease weeds density by 20 and $22 \%$, weeds fresh weight by 20 and $23 \%$ and weeds dry weight by 15 and $21 \%$ in contrast with control [19]. Sunflower water extract spray reduces total weed density by $34 \%$ and increases grain yield of wheat by $5.5 \%$ [20]. The current study was therefore conducted to evaluate the effectiveness of sorghum extract type, concentration and application time on weeds dry weight, cost benefit ratio and harvest index of wheat in agro climatic conditions of Peshawar.

\section{Materials and methods}

The experiment entitled "impact of sorghum extract type, concentration and application time on weeds dry weight, cost benefit ratio and harvest index of wheat" was conducted at Agronomy Research Farm, Agriculture University Peshawar, Pakistan during 201415 in RCBD replicated three times. A plot size of $5.4 \mathrm{~m}^{2}$ was used having six rows each row $0.3 \mathrm{~cm}$ apart and 3 meter long. Atta Habib 2010 wheat cultivar was sown on $27^{\text {th }}$ November, 2015 with seed rate of $120 \mathrm{~kg} \mathrm{ha}^{-1}$. Harvesting was done on $15^{\text {th }}$ May, 2015 manually with sickle when wheat was physiological matured (completely disappearance of green color from kernels and glumes) and each plot was separately 
threshed. A basal dose of fertilizer nitrogen @ 120 and phosphorus @ $90 \mathrm{~kg} \mathrm{ha}^{-1}$ was used. At sowing $1 / 2$ of nitrogen and all the phosphorus were applied whereas, the left over nitrogen fertilizer was applied at the time of first irrigation. The source of nitrogen and phosphorus were urea (46\% $\mathrm{N})$ and di ammonium phosphate (18\% P) respectively. The experiment was composed of two sorghum extract type (leaf water extract and stem water extract), three concentration of extracts $(1: 3,1: 4$ and $1: 5 \mathrm{~kg}$ $\mathrm{L}^{-1}$ ) and three application times (emergence, tillering and $50 \%$ at emergence $+50 \%$ at tillering).Herbicides application, hand weeding and control (no weed check) plots were included for comparison in each replication. No extract was sprayed and no weed check was maintained in control plots.
Weeds were manually uprooted in hand weeded plots. Post emergence herbicides Buctril super 60EC (bromoxynil+MCPA) @ $1.5 \mathrm{~L} \mathrm{ha}^{-1}$ and Puma Super 75EW (fenoxaprop-P-ethyl) @ $1.25 \mathrm{~L} \mathrm{ha}^{-1}$ were applied 45 days after sowing in herbicides treated plots as broad leaf and narrow leaf weedicides respectively. Knapsack hand sprayer was used for application of sorghum water extract and herbicides. Details of water extract preparation of sorghum cultivar (Johar) were reported earlier by [21]. All other agronomic practices such as irrigation and seed bed preparation were kept uniform for all the experimental units. Treatments of the experiments were combined and applied as under.

\begin{tabular}{|c|c|}
\hline T. No & Treatment $(\mathrm{T})$ combination detail \\
\hline T1 & Control (No weed check and no spray) \\
\hline $\mathrm{T} 2$ & Hand weeding (Manual hand weeding by uprooting weeds) \\
\hline T3 & Herbicides application (Buctril @ 1.5 L ha ${ }^{-1}$ and Puma @ 1.25 L ha-1) \\
\hline T4 & Sorghum leaf water extract applied at emergence (E) with 1:3 concentration \\
\hline T5 & Sorghum leaf water extract applied at tillering $(\mathrm{T})$ with $1: 3$ concentration \\
\hline T6 & Sorghum leaf water extract applied $50 \%$ at $\mathrm{E}+50 \%$ at $\mathrm{T}$ with $1: 3$ concentration \\
\hline T7 & Sorghum leaf water extract applied at emergence (E) with 1:4 concentration \\
\hline T8 & Sorghum leaf water extract applied at tillering $(\mathrm{T})$ with $1: 4$ concentration \\
\hline T9 & Sorghum leaf water extract applied $50 \%$ at $\mathrm{E}+50 \%$ at $\mathrm{T}$ with $1: 4$ concentration \\
\hline $\mathrm{T} 10$ & Sorghum leaf water extract applied at emergence $(\mathrm{E})$ with 1:5 concentration \\
\hline T11 & Sorghum leaf water extract applied at tillering $(\mathrm{T})$ with $1: 5$ concentration \\
\hline T12 & Sorghum leaf water extract applied $50 \%$ at $\mathrm{E}+50 \%$ at $\mathrm{T}$ with $1: 5$ concentration \\
\hline T13 & Sorghum stem water extract applied at emergence $(\mathrm{E})$ with 1:3 concentration \\
\hline T14 & Sorghum stem water extract applied at tillering $(\mathrm{T})$ with $1: 3$ concentration \\
\hline T15 & Sorghum stem water extract applied $50 \%$ at $\mathrm{E}+50 \%$ at $\mathrm{T}$ with $1: 3$ concentration \\
\hline T16 & Sorghum stem water extract applied at emergence (E) with 1:4 concentration \\
\hline T17 & Sorghum stem water extract applied at tillering $(\mathrm{T})$ with $1: 4$ concentration \\
\hline T18 & Sorghum stem water extract applied $50 \%$ at $\mathrm{E}+50 \%$ at $\mathrm{T}$ with $1: 4$ concentration \\
\hline T19 & Sorghum stem water extract applied at emergence (E) with 1:5 concentration \\
\hline T20 & Sorghum stem water extract applied at tillering (T) with 1:5 concentration) \\
\hline $\mathrm{T} 21$ & Sorghum stem water extract applied $50 \%$ at $\mathrm{E}+50 \%$ at $\mathrm{T}$ with $1: 5$ concentration \\
\hline
\end{tabular}

\section{Data measurements}

Data were recorded for weeds dry weight, grains spike $^{-1}$, spike weight and harvest index of wheat using standard procedures. For weeds dry weight data, weeds were collected in one square meter area and kept 
for sun drying for one week. Weeds dry weight data was recorded two times (i.e. 70 and 90 days after sowing) in each plot. For grains spike ${ }^{-1}$ data ten representative spikes were harvested from each plot and threshed manually. Each spike grains number were counted and then averaged. For spike weight data ten spikes were harvested randomly from each plot and weighed with digital balance. Average spike weight was taken in gram for further analysis. Harvest index (H.I) of wheat was calculated in percentage using the given equation

$$
\text { H.I }(\%)=\frac{\text { Grain yield }}{\text { Biological yield }} \times 100
$$

\section{Economic analysis}

Following the procedure developed by [22] value cost ratio analysis was performed to find the most economical treatment on the basis of current market price of each input (Table 5). Gross income (G.I), net return (N.R), value cost ratio (V.C.R) and increase cost (I.C) were computed as under.

1. G.I $=$ Grain value + Straw value

2. N.R $=$ G.I - Total cost

3. V.C.R = I.C / Particular cost

4. I.C = Particular G.I - Control G.I

\section{Statistical analysis}

For statistical analysis, the collected data were analyzed using the analysis of variance technique suitable for RCBD. Variation among treatment means were compared using LSD (Least Significant Differences) test at 5\% probability level [23].

\section{Results and discussions}

Weeds dry weight $\left(\mathrm{g} \mathrm{m}^{-2}\right)$

Sorghum extract type, concentration, application time and stages significantly affected weeds dry weight, whereas all the interactions were non-significant (Table 1). More weeds dry weight $\left(82.8 \mathrm{~g} \mathrm{~m}^{-2}\right)$ were recorded 90 days after sowing (DAS) compared 70 DAS which resulted in $65.1 \mathrm{~g}$ $\mathrm{m}^{-2}$ weeds dry weight. Herbicides spayed plots resulted in lighter weeds dry weight (32.1 $\mathrm{g} \mathrm{m}^{-2}$ ) compared with sorghum water extract (SWE) sprayed plots $\left(74.0 \mathrm{~g} \mathrm{~m}^{-2}\right)$. Similarly, hand weeded plots gave lighter weeds dry weight $\left(41.3 \mathrm{~g} \mathrm{~m}^{-2}\right)$ compared with SWE sprayed plots $\left(74.0 \mathrm{~g} \mathrm{~m}^{-2}\right)$. Likewise, SWE sprayed plots resulted in lesser weeds dry weight $\left(74.0 \mathrm{~g} \mathrm{~m}^{-2}\right)$ compared with control plots $\left(112.9 \mathrm{~g} \mathrm{~m}^{-2}\right)$. Mean values for sorghum extract type showed that leaf water extract produced lower weeds dry weight (70.8 $\left.\mathrm{g} \mathrm{m}^{-2}\right)$, whereas stem water extract resulted in higher weeds dry weight $\left(77.2 \mathrm{~g} \mathrm{~m}^{-2}\right)$. Mean values for concentration revealed that lighter weeds dry weight $\left(66.7 \mathrm{~g} \mathrm{~m}^{-2}\right)$ was noted from 1:3 concentration. Weeds dry weight increased with each increase in concentration and more weeds dry weight $\left(81.4 \mathrm{~g} \mathrm{~m}^{-2}\right)$ was noted with 1:5 concentration. Application time showed that SWE sprayed at tillering produced lighter weeds dry weight $\left(68.2 \mathrm{~g} \mathrm{~m}^{-2}\right)$, while SWE sprayed $50 \%$ at emergence $+50 \%$ at tillering resulted in more weeds dry weight $\left(79.8 \mathrm{~g} \mathrm{~m}^{-2}\right)$. Significantly fewer weeds dry weight with herbicides, hand weeding and SWE may be due to reduced weed density and less weeds fresh weight in herbicides treated, hand weeded and SWE sprayed plots respectively. Our results are in line with [19] who reported that herbicide Logron was more effective in reducing weeds compared with hand weeding and SWE sprays. SWE sprayed plots resulted in lower weeds dry weight over control plots. These results are in line with [5, 24-27] who reported fewer weeds dry weight with water extract compared with control. 
Table 1. Weeds dry weight $\left(\mathrm{g} \mathrm{m}^{-2}\right)$ of wheat as affected by sorghum extract type, concentration, application time and stages

\begin{tabular}{|c|c|c|c|}
\hline \multirow{2}{*}{$\begin{array}{c}\text { Sorghum Extract Type } \\
\text { (SET) }\end{array}$} & \multicolumn{2}{|c|}{ Stages } & \multirow[b]{2}{*}{ Mean } \\
\hline & 70 DAS & 90 DAS & \\
\hline Leaf water extract & 62.0 & 79.6 & 70.8 \\
\hline Stem water extract & 68.3 & 86.1 & 77.2 \\
\hline Mean & 65.1 & 82.8 & \\
\hline \multicolumn{4}{|l|}{ Concentration of extract $(\mathrm{C})\left(\mathrm{kg} \mathrm{L}^{-1}\right)$} \\
\hline $1: 3$ & 57.8 & 75.5 & $66.7 \mathrm{c}$ \\
\hline $1: 4$ & 64.9 & 82.8 & $73.9 \mathrm{~b}$ \\
\hline $1: 5$ & 72.6 & 90.2 & $81.4 \mathrm{a}$ \\
\hline \multicolumn{4}{|l|}{ Application time (AT) } \\
\hline Emergence (E) & 65.6 & 82.4 & $74.0 \mathrm{~b}$ \\
\hline Tillering $(\mathrm{T})$ & 59.0 & 77.3 & $68.2 \mathrm{c}$ \\
\hline $50 \%$ at $\mathrm{E}+50 \%$ at $\mathrm{T}$ & 70.8 & 88.7 & $79.8 \mathrm{a}$ \\
\hline \multicolumn{4}{|l|}{ Planned Mean Comparison } \\
\hline Control & 105.4 & 120.4 & 112.9 \\
\hline Sorghum water extract & 65.1 & 82.8 & 74.0 \\
\hline Hand weeding & 33.8 & 48.8 & 41.3 \\
\hline Herbicides application & 24.6 & 39.6 & 32.1 \\
\hline \multicolumn{4}{|l|}{ Interactions } \\
\hline SET x C & NS & $\mathrm{C} \times \mathrm{AT}$ & NS \\
\hline SET x C x AT & NS & SET $x$ AT & NS \\
\hline
\end{tabular}

Means of the same category followed by different letter (s) are significantly different at $\mathrm{P} \leq 0.05$ level using LSD test. LSD for concentration and application time at $\mathrm{p} \leq 0.05=5.1 \quad \mathrm{NS}=$ Non Significant

\section{Grains spike ${ }^{-1}$}

Sorghum extract type, concentration and application time significantly affected grains spike $^{-1}$, whereas all the interactions were non-significant (Table 2). Herbicides sprayed plots produced more grains spike ${ }^{-1}$ (50.9) over SWE sprayed plots (44.6). Likewise, hand weeded plots gave more grains spike ${ }^{-1}$ (50.0) compared with SWE sprayed plots (44.6). Similarly, SWE sprayed plots resulted in more grains spike ${ }^{-1}$ (44.6) compared with control plots (40.6). Mean values for concentration showed that less grains spike ${ }^{-1}$ (42) were noted with 1:5 concentration. Grain spike ${ }^{-1}$ increased with each decrease in concentration and more grain spike $^{-1}$ (47.6) were recorded when
SWE sprayed with 1:3 concentration. Application time showed SWE at tillering gave higher grains spike $^{-1}$ (45.8), while SWE applied at emergence resulted in fewer grains spike $^{-1}$ (43.8), which is statistically similar with SWE applied $50 \%$ at emergence $+50 \%$ at tillering resulted (44.6) grains spike ${ }^{-1}$. Leaf extract gave more grains spike $^{-1}$ (45.3) compared with stem extract (44.1). The increase in grains spike ${ }^{-1}$ with herbicides, hand weeding and SWE may be attributed to the potential weed control in these treatments and as a result wheat crop exploited all the resources and might caused inception of more spikelets and florets spikelet $^{-1}$ in plots where few weeds were recorded. The decrease in grains spikes ${ }^{-1}$ in 
control plots could be due to more competition of wheat crops with weeds plants for nutrients, light, space or water etc. These results are in line with $[5,18]$ who reported more grains spike $^{-1}$ with water extracts compared with control plots. Our results are also in line with [24, 28-30] who reported that herbicides treated plots produced more grains spike $^{-1}$ over hand weeded and SWE sprayed plots.

Table 2. Grains spike $\mathrm{e}^{-1}$ of wheat as affected by sorghum extracts type, concentration and application time

\begin{tabular}{|c|c|c|c|}
\hline \multirow{2}{*}{$\begin{array}{l}\text { Extract Concentration } \\
\text { (C) }\left(\mathrm{kg} \mathrm{L}^{-1}\right)\end{array}$} & \multicolumn{2}{|c|}{ Sorghum Extract Type (SET) } & \multirow[b]{2}{*}{ Mean } \\
\hline & Leaf extract & Stem extract & \\
\hline $1: 3$ & 48.3 & 46.9 & $47.6 \mathrm{a}$ \\
\hline $1: 4$ & 45.3 & 43.7 & $44.5 \mathrm{~b}$ \\
\hline $1: 5$ & 42.3 & 41.3 & $41.8 \mathrm{c}$ \\
\hline \multicolumn{4}{|l|}{ Application Time (AT) } \\
\hline Emergence (E) & 44.3 & 43.3 & $43.8 \mathrm{~b}$ \\
\hline Tillering $(\mathrm{T})$ & 46.3 & 44.7 & $45.5 \mathrm{a}$ \\
\hline $50 \%$ at $\mathrm{E}+50 \%$ at $\mathrm{T}$ & 45.3 & 43.9 & $44.6 \mathrm{~b}$ \\
\hline Mean & 45.3 & 44.0 & \\
\hline \multicolumn{2}{|l|}{ Planned Mean Comparison } & \multicolumn{2}{|l|}{ Interactions } \\
\hline Control & 40.7 & SET x C & NS \\
\hline Sorghum water extract & 44.7 & SET x AT & NS \\
\hline Hand weeding & 50.0 & $\mathrm{C} \times \mathrm{AT}$ & NS \\
\hline Herbicides application & 50.9 & SET x C x AT & NS \\
\hline
\end{tabular}

Means of the same category followed by different letter (s) are significantly different at $\mathrm{P} \leq 0.05$ level using LSD test. LSD for concentration and application time at $\mathrm{p} \leq 0.05=0.84$. NS $=$ Non Significant

\section{Spike weight (g)}

Sorghum extract type, concentration and application time significantly affected spike weight of wheat, whereas all the interactions were non-significant (Table 3). Herbicides treated plots gave more spike weight $(3.40$ g) over SWE sprayed plots (2.74 g). Hand weeded plots resulted in heavier spike weight $(3.20 \mathrm{~g})$ compared with SWE sprayed plots (2.74 g). Similarly, SWE sprayed plots gave more spike weight $(2.74$ g) over control plots (2.40 g). Mean values for concentration showed that less spike weight $(2.61 \mathrm{~g})$ was recorded with 1:5 concentration. Spike weight of wheat increased with each decrease in concentration and more spike weight $(2.87$ g) was recorded with 1:3 concentration. Application time showed that SWE sprayed at tillering gave more spike weight $(2.90 \mathrm{~g})$, whereas SWE applied at emergence gave less spike weight $(2.61 \mathrm{~g})$. Leaf water extract resulted in more spike weight $(2.80$ g) compared with stem water extract $(2.68$ g). These results are in line with [31] who reported more spike weight with herbicides application and water extract of allelopathic crops compared with control plots. 
Table 3. Spike weight (g) of wheat as affected by sorghum extracts type, concentration and application time

\begin{tabular}{|c|c|c|c|}
\hline \multirow{2}{*}{$\begin{array}{l}\text { Extract Concentration } \\
\text { (C) }\left(\mathrm{kg} \mathrm{L}^{-1}\right)\end{array}$} & \multicolumn{2}{|c|}{ Sorghum Extract Type (SET) } & \multirow[b]{2}{*}{ Mean } \\
\hline & Leaf extract & Stem extract & \\
\hline $1: 3$ & 2.93 & 2.81 & $2.87 \mathrm{a}$ \\
\hline $1: 4$ & 2.80 & 2.69 & $2.74 \mathrm{~b}$ \\
\hline $1: 5$ & 2.68 & 2.53 & $2.61 \mathrm{c}$ \\
\hline \multicolumn{4}{|l|}{ Application Time (AT) } \\
\hline Emergence $(\mathrm{E})$ & 2.67 & 2.54 & $2.61 \mathrm{c}$ \\
\hline Tillering $(\mathrm{T})$ & 2.97 & 2.83 & $2.90 \mathrm{a}$ \\
\hline $50 \%$ at $\mathrm{E}+50 \%$ at $\mathrm{T}$ & 2.78 & 2.66 & $2.72 b$ \\
\hline Mean & 2.80 & 2.68 & \\
\hline \multicolumn{2}{|l|}{ Planned Mean Comparison } & \multicolumn{2}{|l|}{ Interactions } \\
\hline Control & 2.40 & SET x C & NS \\
\hline Sorghum water extract & 2.74 & SET $x$ AT & NS \\
\hline Hand weeding & 3.20 & $\mathrm{C} \times \mathrm{AT}$ & NS \\
\hline Herbicides application & 3.40 & SET x C x AT & NS \\
\hline
\end{tabular}

Means of the same category followed by different letter (s) are significantly different at $\mathrm{P} \leq 0.05$ level using LSD test. LSD for concentration and application time at $\mathrm{p} \leq 0.05=0.07$. NS $=$ Non Significant

\section{Harvest index (H.I) (\%)}

Sorghum extract type, concentration and application time significantly affected H.I of wheat, whereas all the interactions were non-significant (Table 4). Herbicides sprayed plots showed higher H.I (37.91\%) compared with SWE sprayed plots (33.77 $\%)$. Likewise, hand weeded plots gave more H.I (36.69 \%) compared with SWE sprayed plots $(33.77 \%)$. Similarly, SWE sprayed plots produced high H.I (33.77 \%) compared with control plots $(30.21 \%)$. Mean values for concentration showed that more H.I $(36.24 \%)$ was reported with 1:3 concentration. H.I of wheat decreased with each increase in concentration and lower H.I $(32.41 \%)$ was noted with 1:5 concentration, which is statistically at par with SWE applied with 1:4 concentration resulted in (32.66 \%) H.I. Application time showed SWE sprayed at tillering produced more H.I (34.36 \%), whereas SWE applied $50 \%$ at emergence +50 at tillering gave less H.I (33.41\%), which is statistically same with SWE applied at emergence resulted in $(33.53 \%)$ H.I. Leaf water extract gave higher H.I (34.04\%) compared with stem water extract (33.49\%). Significantly more H.I with herbicides, hand weeding and SWE sprays may be attributed to more grain and biological yield recorded in these plots compared with control. These results in line with $[25,28,32]$ who reported more H.I with SWE application and $[5,24]$ who reported more H.I with herbicides application. 
Table 4. Harvest index (\%) of wheat as affected by sorghum extracts type, concentration and application time.

\begin{tabular}{|c|c|c|c|}
\hline \multirow{2}{*}{$\begin{array}{l}\text { Extract Concentration } \\
\text { (C) }\left(\mathrm{kg} \mathrm{L}^{-1}\right)\end{array}$} & \multicolumn{2}{|c|}{ Sorghum Extract Type (SET) } & \multirow[b]{2}{*}{ Mean } \\
\hline & Leaf extract & Stem extract & \\
\hline $1: 3$ & 36.32 & 36.15 & $36.24 \mathrm{a}$ \\
\hline $1: 4$ & 32.96 & 32.37 & $32.66 \mathrm{~b}$ \\
\hline $1: 5$ & 32.86 & 31.96 & $32.41 \mathrm{~b}$ \\
\hline \multicolumn{4}{|l|}{ Application Time (AT) } \\
\hline Emergence $(\mathrm{E})$ & 33.68 & 33.37 & $33.53 \mathrm{~b}$ \\
\hline Tillering $(\mathrm{T})$ & 34.82 & 33.90 & $34.36 \mathrm{a}$ \\
\hline $50 \%$ at $\mathrm{E}+50 \%$ at $\mathrm{T}$ & 33.63 & 33.20 & $33.41 \mathrm{~b}$ \\
\hline Mean & 34.04 & 33.49 & \\
\hline \multicolumn{2}{|l|}{ Planned Mean Comparison } & \multicolumn{2}{|l|}{ Interactions } \\
\hline Control & 30.21 & SET x C & NS \\
\hline Sorghum water extract & 33.77 & SET $\times$ AT & NS \\
\hline Hand weeding & 36.69 & C x AT & NS \\
\hline Herbicides application & 37.91 & SET x C x AT & NS \\
\hline
\end{tabular}

Means of the same category followed by different letter (s) are significantly different at $\mathrm{P} \leq 0.05$ level using LSD test. LSD for concentration and application time at $\mathrm{p} \leq 0.05=0.61$. NS $=$ Non Significant

\section{Economic analysis}

Economic analysis of control vs. sorghum water extract (SWE), hands weeding (HW) vs. SWE, herbicide application vs. SWE, sorghum extract type (SET), extract concentration (C) and application time (AT) used in the experiment is presented in Table 5. Herbicides sprayed plots gave higher G.I (Rs. $2087561 \mathrm{ha}^{-1}$ ), N.R (Rs. $175521 \mathrm{ha}^{-1}$ ) and V.C.R (6.6) compared with SWE sprayed plots which resulted in G.I (Rs. 185914 ha $^{-1}$ ), N.R (Rs. 154249 ha $^{-1}$ ) and V.C.R (5.0). Similarly, HW plots resulted in more G.I (Rs. 200493 ha $^{-1}$ ), N.R (Rs. 166853 ha $^{-1}$ ) and V.C.R (5.5) compared with SWE sprayed plots which resulted in G.I (Rs. 185914 ha $^{-1}$ ), N.R (Rs. 154249 ha $^{-1}$ ) and V.C.R (5.0). Economic analysis for SET showed that leaf water extract gave more G.I (Rs. 189630 ha $^{-1}$ ), N.R (Rs. 156760 ha $^{-1}$ ) and less V.C.R (4.8), whereas stem water extract resulted in less G.I (Rs. $186147 \mathrm{ha}^{-1}$ ) more N.R (Rs. $157133 \mathrm{ha}^{-1}$ ) and more V.C.R (7.6). Economic analysis for concentration indicated that more G.I (Rs. 194646 ha $^{-1}$ ), N.R (Rs. 162252 ha $^{-1}$ ) and V.C.R (5.6) were recorded with 1:3 concentration, whereas less G.I (Rs.177215 ha ${ }^{-1}$ ), N.R (Rs. 147505 $\mathrm{ha}^{-1}$ ) and V.C.R (5.2) were resulted with 1:5 concentration. Economic analysis for AT showed that more G.I ( Rs. 188036 ha $^{-1}$ ), N.R (Rs. $157094 \mathrm{ha}^{-1}$ ) and V.C.R (5.8) were with SWE applied at tillering, whereas less G.I (Rs. 183437 ha $^{-1}$ ), N.R (Rs. 150495 ha $^{-1}$ ) and V.C.R (4.1) were reported with SWE applied $50 \%$ at emergence $+50 \%$ at tillering. These results are in line with [18, 24, 33] who reported that herbicides gave higher net benefit compared with hand weeding and SWE spray. Our results are also in line with [33] who reported that concentrated extract (1:10) gave more net income compared with diluted extract (1:20). 
Table 5. Shows economic analysis of control vs. sorghum water extract, hands weeding vs. sorghum water extract, herbicides treatment vs. sorghum water extract, sorghum extract type, extract concentration and application time

\begin{tabular}{|c|c|c|c|c|c|c|c|c|c|c|}
\hline $\begin{array}{l}\text { Particular } \\
\text { (P) }\end{array}$ & $\begin{array}{c}\text { Grain } \\
\text { yield } \\
\left(\mathrm{kg} \mathrm{ha}^{-1}\right)\end{array}$ & $\begin{array}{c}\text { Straw } \\
\text { yield } \\
\left(\mathrm{kg} \mathrm{ha}^{-1}\right)\end{array}$ & $\begin{array}{l}\text { Grain } \\
\text { value } \\
(\text { PKR) }\end{array}$ & $\begin{array}{c}\text { Straw } \\
\text { value } \\
(\mathrm{PKR}) \\
\end{array}$ & $\begin{array}{c}\text { Gross } \\
\text { income } \\
(\mathrm{PKR})\end{array}$ & $\begin{array}{c}\mathbf{P} \\
\text { cost } \\
(\mathbf{P K R})\end{array}$ & $\begin{array}{c}\text { Total } \\
\text { cost } \\
(\text { PKR) }\end{array}$ & $\begin{array}{c}\text { Increase } \\
\text { Cost } \\
(\text { PKR })\end{array}$ & $\begin{array}{c}\text { Net } \\
\text { return } \\
(\text { PKR) }\end{array}$ & VCR \\
\hline Control & 2347 & 5420 & 75104 & 70460 & 145564 & - & 23640 & - & 121924 & - \\
\hline Sorghum water extract & 3222 & 6370 & 103104 & 82810 & 185914 & 8025 & 31665 & 40350 & 154249 & 5.0 \\
\hline Hand weeding & 3683 & 6357 & 117856 & 82637 & 200493 & 10000 & 33640 & 54929 & 166853 & 5.5 \\
\hline Sorghum water extract & 3222 & 6370 & 103104 & 82810 & 185914 & 8025 & 31665 & 40350 & 154249 & 5.0 \\
\hline Herbicides application & 3917 & 6417 & 125344 & 83417 & 208761 & 9600 & 33240 & 63197 & 175521 & 6.6 \\
\hline Sorghum water extract & 3222 & 6370 & 103104 & 82810 & 185914 & 8025 & 31665 & 40350 & 154249 & 5.0 \\
\hline \multicolumn{11}{|c|}{ Sorghum Extract Type (SET) } \\
\hline Leaf water extract & 3330 & 6390 & 106560 & 83070 & 189630 & 9230 & 32870 & 44066 & 156760 & 4.8 \\
\hline Stem water extract & 3237 & 6351 & 103584 & 82563 & 186147 & 5374 & 29014 & 40583 & 157133 & 7.6 \\
\hline \multicolumn{11}{|c|}{ Extract Concentration (C) $\left(\mathrm{kg} \mathrm{L}^{-1}\right)$} \\
\hline $1: 3$ & 3547 & 6242 & 113504 & 81142 & 194646 & 8754 & 32394 & 49082 & 162252 & 5.6 \\
\hline $1: 4$ & 3122 & 6436 & 99904 & 83669 & 183573 & 7082 & 30722 & 38009 & 152851 & 5.4 \\
\hline $1: 5$ & 2998 & 6252 & 95936 & 81279 & 177215 & 6070 & 29710 & 31651 & 147505 & 5.2 \\
\hline \multicolumn{11}{|l|}{ Application Time (AT) } \\
\hline Emergence $(\mathrm{E})$ & 3208 & 6331 & 102656 & 82297 & 184953 & 7302 & 30942 & 39389 & 154011 & 5.4 \\
\hline Tillering (T) & 3312 & 6312 & 105984 & 82052 & 188036 & 7302 & 30942 & 42472 & 157094 & 5.8 \\
\hline $50 \%$ at $\mathrm{E}+50 \%$ at $\mathrm{T}$ & 3178 & 6288 & 101696 & 81741 & 183437 & 9302 & 32942 & 37873 & 150495 & 4.1 \\
\hline
\end{tabular}

Current market price for wheat grain and straw Rs. $32 \mathrm{~kg}^{-1}$ and Rs. $13 \mathrm{~kg}^{-1}$ respectively.

Herbicides price (Buctril Super 60EC Rs. 695 per $300 \mathrm{ml}$ and Puma Super 75EW Rs. 1040 per $500 \mathrm{ml}$ ).

Labor cost for hand weeding Rs. 500 per person per day @ 1 kanal area. 


\section{Conclusion}

It is concluded that leaf water extract applied with 1:3 concentration sprayed at tillering reduced weeds dry weight and increased grains spike $^{-1}$, spike weight and harvest index of wheat and is recommended for decreasing weeds dry weight and increasing H.I of wheat and farmer profit in agro climatic condition of Peshawar.

\section{Authors' contributions}

Conceived and designed the experiments: SK Khalil \& A Rab, Performed the experiments: A Rab, H Nawaz, G Sadiq, I Ali \& F Khan, Analyzed the data: A Rab, SK Khalil, H Raza \& M Asim, Contributed reagents/materials/analysis tools: A Rab, A Khan, M Asim \& N Mehmood, Wrote the paper: A Rab \& SK Khalil

\section{References}

1. Steinfeld H \& Opio C (2010). The availability of feeds for livestock: Competition with human consumption in present world. Advances in Animal Biosciences 1(2): 421-475.

2. MNFSR (2014). Ministry of National Food Security and Research, Agricultural Statistics, Economic Wing, Government of Pakistan, Islamabad. Data accessed: December 2014. Available at: http://www.mnfsr.gov.pk.

3. USDA (2014). United States Department of Agriculture. Agricultural Statistics, World Agricultural Outlook Board (WAOB). Data accessed: December 30, 2014. Online available at: http://apps.fas.usda.gov/psdonline/circulars /production. pdf.

4. Afridi RA \& Khan MA (2014). Reduced herbicides doses in combination with allelopathic plant extracts suppress weeds in wheat. Pak J Bot 46(6): 2077-2082

5. Khan EA, Khakhwani AZ, Munir M \& Ullah G (2015). Effect of allelopathic chemicals extracted from various plant leaves on weed control and wheat crop productivity. Pak J Bot 47(2): 735-740.

6. Noor K, Khan EA, Baloch MS, Khan MA, Ullah I, Sadiq M \& Aslam M (2013).
Allelopathic effect of congress grass on weeds and yield of wheat. Pak J Weed Sci Res 18(3): 307-318.

7. Ashiq M, Muhammad N \& Ahmad N (2006). Comparative efficacy of different herbicides to control grassy weeds in wheat. Pak J Weed Sci Res 12:157-161.

8. Jabran K, Cheema ZA, Farooq M \& Hussain M (2010). Lower doses of pendimethalin mixed with allelopathic crop water extracts for weed management in canola (Brassica napus). Int J Agric Biol 12: 335-340.

9. Abdellkarim MM, Gualandi RJ, Gwinn KD \& Ownley BH (2010). Impact of mycorrhizal infection on sensitivity of wheat to sorghum allelopathy. Phytopathology 100:52.

10. Weir TL, Park SW \& Vivanco JM (2004). Biochemical and physiological mechanisms mediated by allelochemicals. Current Opinion in Plant Biology 7:472479.

11. Alsaadawi IS, Al-Ekeelie MHS \& AlHamzawi MK (2007). Differential allelopathic potential of grain sorghum genotypes to weeds. Allelopathy J. 19:153160.

12. Chon SU \& Kim JD (2002). Biological activity and quantification of suspected allelochemicals from alfalfa plant parts. $J$ Agron Crop Sci 188(4): 281-285.

13. Jabran K \& Farooq M (2012). Implications of potential allelopathic crops in agricultural systems. In: Allelopathy: Current Trends and Future Applications, pp: 349-385. Cheema, Z. A., M. Farooq and A. Wahid (eds.). Springer: Verlag Berlin Heidelberg, Germany.

14. Hassan MM, Daffalla HM, Yagoub SO, Osman MG, Gani AME \& Babiker AGE (2012). Allelopathic effects of some botanical extracts on germination and seedling growth of Sorghum bicolor L. Int J of Agri Tech 8 (4): 1423-1469.

15. Tesio F \& Ferrero A (2010). Allelopathy a chance for sustainable weed management. Int. J. Sustain. Develop. World Ecol 17 (5): 377-389. 
16. Ghafarbi SP, Hassannejad S \& Lotfi R (2010). Allelopathic effects of wheat seed extracts on seed and seedling growth of eight selected weed species. Int J of Agric Crop Sci 4(19):1452-1457.

17. Jabran K, Cheema ZA, Farooq M, Basra SMA, Hussain M \& Rehman H (2008). Tank mixing of allelopathic crop water extracts with pendimethalin helps in the management of weeds in canola (Brassica napus) field. Int J Agric Biol 10(3): 293296.

18. Cheema ZA \& Khaliq A (2000). Use of sorghum allelopathic properties to control weeds in irrigated wheat in a semi arid region of Punjab. Agric Ecos Environ 79: 105-112.

19. Ashraf M \& Akhlaq M (2007). Effects of sorghum leaves, roots and stems water extract, hand weeding and herbicide on weeds suppression and yield of wheat. Sarhad J Agri 23: 321-328.

20. Cheema ZA, Khaliq A \& Mubeen M (2003). Response of wheat and winter weeds to foliar application of different plant water extracts of sorghum (Sorghum bicolor). Pak J Weed Sci Res 9 (1, 2): 8997.

21. Rab A, Khalil SK, Asim M, Mehmood N, Fayyaz H, Khan I, Zahid S \& Nawaz H (2016). Response of sorghum (Sorghum bicolor L.) extract type, concentration and application time to weeds weight, grain and biomass yield of wheat. Pure Appl. Biol 5(4):

850-558. http://dx.doi.org/10.19045/bspab.2016.501 06.

22. Amanullah, Almas LK \& Shah P (2010). Timing and rate of nitrogen application influence profitability of maize planted at low and high densities in Northwest Pakistan. Agronomy J 102: 575-579.

23. Steel RGD, Torrie JH \& Dicky DA (1997). Principles and Procedures of Statistics, A Biometrical Approach. 3rd Ed. McGraw Hill, Inc. Book Co. N.Y. USA. pp. 352-358.

24. Arif M, Cheema ZA, Khaliq A \& Hassan A (2015). Organic weed management in wheat through allelopathy. Int J Agric Biol 17(1):127-134.

25. Awan FK, Rasheed M, Ashraf M \& Khurshid MY (2012). Efficacy of brassica sorghum and sunflower aqueous extracts to control wheat weeds under rainfed conditions of Pothwar. Pak. J. Anim. Pl. Sci 22: 715-721.

26. Shahid M, Ahmad B, Khattak RA \& Arif M (2007). Integration of herbicides with aqueous allelopathic extracts for weeds control in wheat. African Crop Science Conference Proceedings 8: 209-212.

27. Hussain S, Hassan F, Rasheed M, Ali S \& Ahmad M (2014). Effects of allelopathic crop water extracts and their combinations on weeds and yield of rainfed wheat. $J$ of Food Agri \& Envin 12 (3-4):161-167.

28. Cheema ZA, Iqbal M \& Ahmad R (2002). Response of wheat varieties and some rabi weeds to allelopathic effects of sorghum water extract. Int J Agri Biol 52-55.

29. Cheema ZA, Khaliq A \& Akhtar S (2001). Use of sorghum water extract as a natural weed inhibitor in spring mungbean. Int $J$ Agric Biol 3: 515-518.

30. Sohail N (2009). Efficacy of weedicides to control broad leaf weeds in wheat. M.Sc. Thesis, Department of Agronomy, University of Agriculture, Faisalabad, Pakistan.

31. Khan AI, Awan IU, Mansoor M, Khan EA, Khakwani AA \& Baloch MS (2011). Efficacy and economic analysis of plants aqueous exudates on physiological parameters of wheat. Pak J Weed Sci Res 17(4): 417-424.

32. Jamil M, Cheema ZA, Mushtaq MN, Farooq M \& Cheema MA (2009). Alternative control of wild oat and canary grass in wheat fields by allelopathic plant water extracts. Agron Sustain Dev 29: 475482.

33. Cheema ZA, Sadiq HMI \& Khaliq A (2000). Efficacy of sorgaab (sorghum water extract) as a natural weed inhibitor in wheat. Int J Agric Biol 2:144-146. 